\section{REUSING WRITING ASSIGNMENTS}

\author{
BY JAMES D. DIMITRI
}

James Dimitri holds the position of Clinical Associate Professor of Law at the Indiana University School of Law-Indianapolis, where he teaches Legal Analysis, Research, and Communication, and Advanced Persuasive Writing and Oral Advocacy. Before his appointment to the IU-Indianapolis faculty, Professor Dimitri practiced law with the Indiana Attorney General's Office as a deputy attorney general. The focus of his practice was federal and state appeals, federal habeas corpus litigation, and tort litigation.

Brutal Choices in Curricular Design ... is a regular feature of Perspectives, designed to explore the difficult curricular decisions that teachers of legal research and writing courses are often forced to make in light of the realities of limited budgets, time, personnel, and other resources. Readers are invited to comment on the opinions expressed in this column and to suggest other "brutal choices" that should be considered in future issues. Please submit material to Helene Shapo, Northwestern University School of Law, 357 East Chicago Avenue, Chicago, IL 60611, phone: (312) 503-8454, fax: (312) 5032035.

At the Indiana University School of Law-Indianapolis, the faculty who teach our firstyear legal research and writing course, Legal Analysis, Research, and Communication (LARC), are responsible for creating their own problems for the majority of the writing assignments. As my teaching career has progressed, I have built a growing bank of writing assignments, ranging from objective memoranda to appellate brief assignments. Now that I have this bank of assignments, I have become very tempted to reuse problems rather than create new ones. This temptation has grown recently since I seem to get busier with each year of teaching, and therefore find myself with less time to research and write problems for LARC assignments.

But while reusing problems saves some time, it unfailingly presents me with several issues that I must consider and resolve. In an effort to provide guidance to other legal research and writing faculty who are faced with the decision to reuse writing assignments, I will discuss what I consider before I decide to reuse an assignment and how I resolve those issues.

\section{Closed Versus Open Assignments}

Our LARC course, like legal research and writing courses at many other schools, begins with several closed assignments. The entire LARC department at my school, led by our program director, assembles these assignments because all first-year students receive the same closed assignments. The assignments are "closed" because the students are not permitted to do independent research to gather authorities to support the analysis in their papers. Rather, at the time each closed assignment is handed out, I and my LARC colleagues provide the legal authorities students will use to support their written analysis.

Later assignments in the course are "open," which means that the students are required to do independent research. Unlike the closed assignments, open assignments are not departmentwide assignments at my school; rather, each individual LARC professor creates his or her own open assignments.

I have found closed assignments easier to reuse than open assignments for a couple of reasons. First, with closed assignments, I do not have to update the legal authorities upon which the assignment is based. In other words, even if the law that governs a closed assignment changes due to a judicial decision or legislative amendment, I am still free to use the same legal authorities containing the "old" or superseded law because I
${ }^{6}$ As my teaching

\section{career has}

progressed,

I have built a

growing bank of

writing

assignments,

ranging from

objective

memoranda to appellate brief

assignments. ${ }^{9}$ 


\section{8}

\section{"I find that the}

\section{best sources}

\section{for law-}

\section{centered}

issues are

jurisdictions in

which there is

a split of

authority on a

legal issue." control the sources of the law that the students will use in their papers.

In contrast, I cannot completely control the authorities that the students will use in an open assignment because the students, not me, are responsible for gathering the legal authorities that will govern their analysis. Moreover, the law governing the assignment may have changed since I first assigned the problem, requiring me to consider adding new sources of law if I reuse the assignment or abandoning the assignment altogether if the change in the law is drastic. For instance, I recently discarded an open office memorandum assignment involving the issue of whether, under Indiana law, a plaintiff could recover emotional distress damages that allegedly resulted from a defendant's negligence. One issue that the students had to discuss was whether the plaintiff suffered a direct physical impact as a result of the defendant's negligence, which was a prerequisite to the recovery of emotional distress damages. I can no longer use this assignment because the Indiana Supreme Court abrogated the direct physical impact requirement after I first gave out the assignment. In sum, because reusing open assignments requires me to update the law governing the assignment, I am less likely to reuse open assignments than I am closed assignments.

The second reason that I find closed assignments easier to reuse is that closed assignments in my LARC course are usually simpler in subject matter and scope than the open assignments. This simplicity exists because the closed assignments are designed to teach the students basic writing, analytical, and organizational skills, whereas the open assignments are designed to refine these basic skills and to teach new skills. Because the closed assignments are simpler than the open assignments, the closed assignments also tend to be shorter. The simplicity and brevity of the closed assignments require me to spend less time reviewing those assignments when deciding whether to reuse them, thus making it easier for me to reuse the assignment.
Although I find closed assignments to be easier to reuse, reusing a closed assignment based upon superseded legal authority does present a danger: the students may mistakenly believe that the superseded authority represents the current state of the law. To this point in my teaching career, I have not reused a closed assignment following a change in the law governing that assignment. ${ }^{1}$ If, however, I ever decide to reuse a closed assignment based upon a superseded legal doctrine, I will inform the students after they have completed the assignment that the law governing the assignment has changed. That way, the students will not mistakenly believe that the superseded authority represents the current state of the law.

\section{Objective Versus Persuasive Assignments}

I also consider whether the assignment is an objective memorandum or a persuasive brief. In my school's writing program, first-year students taking LARC are assigned two major objective papers and one persuasive paper. The objective assignments are office memoranda and the persuasive assignment is an appellate brief.

Over the past several years, I have more frequently reused office memoranda than I have appellate brief assignments because appellate brief assignments are often later "mooted" by a subsequent appellate court decision. More specifically, my appellate brief assignments almost always involve law-centered issues, where the students must analyze the interpretation of a statute or constitutional provision, or where they must debate the adoption of a new common law doctrine. I find that the best sources for lawcentered issues are jurisdictions in which there is a split of authority on a legal issue. Federal splits of authority occur when two or more federal circuits disagree on the resolution of a legal issue; state splits of authority occur when different districts or panels of a state's intermediate appellate court disagree on the resolution of a legal issue. Most splits of authority are eventually resolved by the

\footnotetext{
${ }^{1}$ The main reason I have never reused a closed assignment following a change in the law is that our program's closed assignments are typically set in a fictional jurisdiction and are based upon fictional statutes or case law, which, of course, are not subject to change through a later legislative amendment or judicial decision.
} 
jurisdiction's highest court-the U.S. Supreme Court for federal circuit splits and the state supreme courts for splits among the districts or panels of the states' intermediate appellate courts. ${ }^{2}$ If I choose an appellate brief assignment based upon a split of authority that is later resolved by the jurisdiction's highest court, the assignment is mooted and thus impossible to reuse.

In contrast to my appellate brief assignments, my office memorandum assignments usually involve fact-centered issues, where the students must apply an established rule of law to the facts that I have provided in the assignment. For example, my latest office memorandum assignment, which was a fact-centered assignment, was about the application of Indiana's testimonial privilege for physicians, a well-established legal rule that has existed in Indiana since the 1800s. Because my office memorandum assignments are normally based upon an established rule of law and not a split of authority, they are less likely to be mooted by subsequent judicial decisions or legislative actions. As a result, I can reuse these assignments more frequently than appellate brief assignments.

If I wish to reuse an assignment involving a law-centered issue, particularly an assignment based upon a split of authority, I have to thoroughly update the law upon which the problem is based to make sure that the problem has not been mooted. For instance, for a problem based upon a split of authority among the federal circuits, I check to see if the U.S. Supreme Court has resolved the split. If the Court has not resolved the circuit split, then I check the Court's docket to see if the Court has granted certiorari to resolve the circuit split. ${ }^{3}$ If the Court has granted certiorari but will not hear oral argument in the case until

${ }^{2}$ If I choose an appellate brief problem based upon a split of authority, I normally set the problem in the jurisdiction's highest court, in a fictional jurisdiction, or in an intermediate appellate court that has never considered the issue, rather than in one of the intermediate appellate courts involved in the split. That way, the students representing the appealing party are not forced in the assignment to try to overcome binding authority in the circuit when writing their briefs. For instance, I set appellate brief problems involving a federal circuit split in the U.S. Supreme Court or in the fictional Thirteenth Circuit rather than in one of the circuits involved in the split.

${ }^{3}$ To check the Court's docket, you may consult the Court's official Web site at <www.supremecourtus.gov>. after the students turn in the assignment, then I may reuse the problem without the risk that it will be mooted while the students are working on it. In this instance, however, the parties in the case will have already briefed the appeal. These briefs are usually available from a number of sources, such as Westlaw $^{\circledR}$. Therefore, if I reuse this type of assignment, I forbid my students from consulting the parties' briefs when writing their own briefs.

\section{The Subject Matter of Open Assignments}

When I begin evaluating an open writing assignment for reuse, I consider the subject matter of the assignment. In particular, I think about whether the assignment is based upon an area of the law that changes frequently. If the assignment covers such an area of law, I usually must spend more time updating the assignment than I would an assignment based upon an area of law that remains static. Therefore, it is typically easier for me to reuse problems based upon legal doctrines that stay relatively static.

By way of example, I find that property law tends to remain fairly static. For instance, I previously reused a problem involving the doctrine of adverse possession, which required me to do little updating of the sources used in the problem. In contrast, tort law tends to change more frequently. My open office memorandum assignment involving the issue of emotional distress damages is a good example of a tort law problem that I can no longer use because of a change in the law.

\section{The Risk of Academic Misconduct}

Fortunately, I have had to deal with only one instance of academic misconduct during my teaching career. Yet the risk of academic misconduct is still an issue that I must consider when deciding to reuse a writing assignment. Firstyear students often consult with second- and third-year students about dealing with law school. 
While many of these conversations cover topics such as effective study habits or which professors to take for classes, these conversations sometimes involve the assignments from the LARC course.

To prevent second-and third-year students from sharing information about old LARC assignments with first-year students, the LARC faculty at my school impose a moratorium on assignment reuse. Under that moratorium, all of us wait four years before we reuse a writing assignment. ${ }^{4}$ The four-year moratorium period ensures that all students who were assigned a writing assignment graduate before the assignment is reused.

Unfortunately, our moratorium does not eliminate all potential sources of plagiarism. Specifically, student organizations, such as law fraternities, compile banks of past writing problems and old papers, which students who belong to those organizations can review. Similarly, a number of Web sites on the Internet contain databases of essays and papers. ${ }^{5}$ Students who access these Web sites can purchase papers for a fee and then submit them as their own work, thereby committing digital plagiarism. ${ }^{6}$

Preventing academic misconduct stemming from paper banks and online sources can be difficult. I, however, use two techniques to thwart plagiarism from these sources when I reuse a problem. First, I change the names of the parties involved in the problem to make it more difficult for students to locate old papers in paper banks and on Internet databases. Second, I change the facts in the problem to ensure that the students' written analysis will differ from the written analysis in the papers that were submitted the first time I used the problem. For example, several years ago, I used an office memorandum problem

${ }^{4}$ The period is four years instead of three because my school has a four-year, part-time program in addition to the traditional three-year, full-time program, and most of the LARC faculty teach a group of part-time students each academic year.

5 See, e.g., <www.cheathouse.com>; <www.fastpapers.com>.

${ }^{6}$ Of course, if the law governing a writing problem has substantially changed since the first time the problem was used, plagiarism will be thwarted as a practical matter because students must write papers that will be analytically different from the papers the students submitted when the problem was first assigned. My discussion of plagiarism here assumes that the law governing the problem has not changed since the problem was first assigned. in which the students had to discuss whether a defendant was liable under one theory of liability. When I reused the problem, I altered the facts of the problem so the students had to discuss whether the defendant was liable under two theories of liability.

In addition, I am aware of at least one Web site that offers tools to detect digital plagiarism. ${ }^{7}$ These tools are offered for a subscription fee and allow users to compare the content of submitted papers with content located on the Internet. I have never used this Web site, but research and writing teachers may want to investigate it to see if it is useful and economical.

\section{The Feasibility of the Assignment}

Perhaps the most important consideration in reusing a problem is the feasibility of the assignment. Before I reuse a writing assignment, I always look at how well the assignment worked the first time I assigned it. More specifically, I examine whether the assignment was a good tool for teaching the skills ${ }^{8}$ that were the goal of the assignment. If an assignment was a good teaching tool the first time around, I am more likely to reuse it than an assignment that was not an effective teaching tool.

For instance, when I consider whether a closed assignment was a good teaching tool, I examine whether the assignment successfully tested the students' basic analytical and organizational skills the first time that I assigned it. In general, I find that closed assignments based upon criminal law or intentional torts are good for developing basic analytical skills, such as identifying the elements of a cause of action. For example, both the crime of burglary and the intentional tort of battery provide a good basis for closed assignments because both have easily identifiable elements. Therefore, I am more likely to reuse a closed

\footnotetext{
7 See <www.turnitin.com>.

8 "Skills" in this context means analytical and organizational skills, not grammatical skills or writing mechanics.
} 
assignment based upon these topics than assignments based upon other areas of law.

Similarly, when I consider whether an appellate brief assignment was a good teaching tool, I examine whether the assignment successfully tested the students' persuasive writing skills the first time around. In my experience, brief assignments involving a law-centered issue, such as constitutional interpretation, are good for developing persuasive writing skills. A few years ago, I assigned an appellate brief problem that involved the issue of whether an attorney who sleeps during short portions of his client's criminal trial violates per se his client's right to the effective assistance of counsel under the Sixth Amendment. This problem worked quite well because students had to craft several public policy arguments to support their positions, which is a skill that they were not required to use in their previous writing assignments. Therefore, barring a change in the law that moots the problem, the problem is a good candidate for reuse.

In addition, when I consider the feasibility of reusing an assignment, I always think about whether the students enjoyed the assignment the first time that I gave it. While it is not always possible to assign a problem that the students will enjoy, I try not to give boring assignments. In my experience, boring assignments are poor tools to teach students writing skills because the students are not enthusiastic about tackling the challenges that the assignment presents. I find that assignments on dry subjects, such as workers' compensation, do not pique the students' interest. Furthermore, if an assignment was boring for the students to write, it will probably be just as boring to me when I grade the assignment. As a consequence, I try to reuse problems that engaged my students intellectually and continue to engage me intellectually.

C) 2003 James D. Dimitri 